\title{
NUT Family Member 2A
}

National Cancer Institute

\section{Source}

National Cancer Institute. NUT Family Member 2A. NCI Thesaurus. Code C101100.

NUT family member 2A (878 aa, $294 \mathrm{kDa}$ ) is encoded by the human NUT M2A gene. This protein has an unknown function. 